\title{
Financial management to support sustainability
}

\author{
Doug Cerf and Arline Savage
}

\section{Introduction}

Sustainability provides an important focus for financial managers. This chapter presents state-of-the-art financial tools and techniques that support sustainability goals. The primary purpose is to introduce markets, investments, reporting techniques, and analytical methods that can be used by firms to support sustainability.

We present the tools and techniques in three financial management categories: finance, internal reporting, and external reporting. The finance category relates to resource allocation, management, acquisition, and investment. The internal reporting category is accounting-related and is concerned with providing information to management for internal decision making. The external reporting category is also accounting-related and is directed toward providing information to outsiders, such as shareholders, financial analysts, creditors, prospective investors and employees, social activists, and the public in general.

Firms that implement accounting and finance tools to support sustainability are in one of two general categories. The first category consists of fims for which sustainable development is a strategic objective. The second category consists of firms that have separate envirommental and occupational health departments. an arrangement that generally indicates or leads to weak integration of sustainability objectives into the firm's strategy.

The challenge for tirms in the first category is 10 implement the sustainability tools throughout the organization. The goals of incorporating sustamability in the strategic plan of the firm are: (1) to create long-term economic sustainability: (2) to generate value through a system of corporate social responsibility; and (3) to generate value through envirommental management (e.g., Kaplan and De Pinho 2007: 5). Issues that firms face in this category include implementation across divisions of the firm. Divisions maly need to modify a specific sustainability tool to be consistent with the characteristics of the business. In an intemational environment. implementation is complicated by local management tradition. To encourage management buy-in, firms may consider linking outcones from use of the finance and accounting sustainability tools to a compensation incentive system.

Firms have developed environmental and occupational health departments as they have evolved in their efforts to address sustainability issues. In some cases environmental and occupational health departments have operated in isolation 
from the main management of the firm. The challenge for the environmental and occupational health departments in these firms is to attract the attention of upper management to incorporate sustainability initiatives into the strategic plan. Reporting by the head of the environmental and occupational health deparment to top management increases the likelihood that these issues will be incorporated in the strategic plan. Once implementation into the strategic plan is achieved, success of the sustainability initiatives by the environmental and occupational health departments is more likely.

Once sustainability is embedded in a firm's strategic plan, financial managers have a critical role in addressing and reporting on the economic impact of sustainable business activities. In the next section we will discuss the prominent finance tools and techniques that financial managers can use to support sustainability.

\section{Finance tools and techniques}

Table 10.1 summarizes finance tools and techniques by presenting disciplinary roots, key contributors, a short description, stakeholders, and the outcomes that result from using the tool or technique.

Table 10.1 Summary of finance tools and techniques

\begin{tabular}{|c|c|c|c|}
\hline & $\begin{array}{l}\text { Socially responsible } \\
\text { investing }\end{array}$ & $\begin{array}{l}\text { Social return on } \\
\text { investment }\end{array}$ & $\begin{array}{l}\text { Emissions mading } \\
\text { programs }\end{array}$ \\
\hline $\begin{array}{l}\text { Disciplinary } \\
\text { roots }\end{array}$ & $\begin{array}{l}\text { Finance and } \\
\text { investments in debt } \\
\text { and equity }\end{array}$ & $\begin{array}{l}\text { Finance and financial } \\
\text { retum metrics }\end{array}$ & $\begin{array}{l}\text { Finance and slock } \\
\text { markets }\end{array}$ \\
\hline $\begin{array}{l}\text { Key } \\
\text { contributors }\end{array}$ & $\begin{array}{l}\text { Social investment } \\
\text { forums }\end{array}$ & $\begin{array}{l}\text { Lingane and Olsen } \\
(2004)\end{array}$ & $\begin{array}{l}\text { United States } \\
\text { Environmential } \\
\text { Protection Agency } \\
\text { and European Union }\end{array}$ \\
\hline $\begin{array}{l}\text { Description } \\
\text { of tool or } \\
\text { technique }\end{array}$ & $\begin{array}{l}\text { Investment strategy } \\
\text { that allows firms to } \\
\text { invest their capital in } \\
\text { investments that are } \\
\text { consistent with } \\
\text { sustainability goals }\end{array}$ & $\begin{array}{l}\text { Return metric that } \\
\text { includes social retum } \\
\text { in currency units } \\
\text { compared to currency } \\
\text { units invested }\end{array}$ & $\begin{array}{l}\text { Trading market } \\
\text { where participants } \\
\text { buy and sell the } \\
\text { right } 10 \text { emil } \\
\text { pollutants (e.g.s } \\
\text { greenhouse gases) }\end{array}$ \\
\hline Stakeholders & $\begin{array}{l}\text { Society, shareholders, } \\
\text { employees, fund } \\
\text { managers }\end{array}$ & $\begin{array}{l}\text { Investors, } \\
\text { management, fund } \\
\text { managers, venture } \\
\text { capitalists }\end{array}$ & $\begin{array}{l}\text { Sociely, future } \\
\text { generations, } \\
\text { government enities }\end{array}$ \\
\hline Outcomes & $\begin{array}{l}\text { Provides an } \\
\text { investment outlet for } \\
\text { investors who support } \\
\text { sustainability. Provides } \\
\text { an additional source of } \\
\text { capital for firms with } \\
\text { a sustainable mission }\end{array}$ & $\begin{array}{l}\text { Provides stakeholders } \\
\text { wilh a tool that allows } \\
\text { them to evaluate the } \\
\text { social return for the } \\
\text { amount of investment }\end{array}$ & $\begin{array}{l}\text { Reduction in } \\
\text { pollutants in the alr: } \\
\text { healthier humans } \\
\text { and animals }\end{array}$ \\
\hline
\end{tabular}


Next, we provide a more detailed explanation of each tool and we explain how it supports sustainability.

\section{Socially Responsible Investing}

Socially Responsible Investing (SRI) allows firms to invest their short- and long-term capital into investments that are consistent with sustainability goals. The goal of SRI is to achieve competitive financial returns while fostering better social and environmental performance. Firms may use the following strategies to achieve SRI objectives: (1) investing in companies that meet certain social and/or environmental performance criteria; (2) using their rights as shareowners to encourage companies to be better corporate citizens; and/or (3) allocating some of the fund's assets for investment in disadvantaged urban and rural communities.

SRl mutual funds are an increasingly popular SRI vehicle. For example, in the United States socially responsible investment assets under professional management grew 4 percent faster than the entire universe of managed assets over the period 1995 to 2005. During this period, SRI mutual fund assets increased by 258 percent, from $\$ 639$ billion in 1995 to $\$ 2.29$ trillion in 2005. In 2005 , nearly $\$ 1$ out of every $\$ 10$ under professional management was in socially responsible investing, or 9.4 percent of the $\$ 24.4$ trillion under professional management (Social Investment Forum 2006).

SRI supports sustainability by allowing firms to invest their short- and longterm capital into investments that are consistent with sustainability goals. It allows firms to support other firms that have a sustainable mission (e.g., renewable energy), and may also support firms that do not have a sustainable mission, but operate in a sustainable manner.

\section{Social Return on Investment}

Social Return on lnvestment (SROl) allows firms to evaluate projects based on social return as well as tinancial returns. SROl provides investors and managers with a tool to support sustainability in their investment decisions. SROI is a complement to financial return on investment. SROI assists managers to optimize the impact of their operation on the environment and human well-being while achieving the shareholder relums that stockholders expect. By being able to measure SROI, managers and investors (e.g., venture capitalists) can help entrepreneurs as they plan their business to identify business model modifications or alternatives as well as market opportunities that could result in increased social benefit. Familiarity with SROl assists management with ongoing operational management and capital allocation decisions by helping them maximize both the social and financial bottom line. It also helps facilitate assessment of investment opportunities and their performance with respect to investors 'specific social and financial goals. Lingane and Olsen (2004) provide steps and an example of a SROl calculation. 
SROI is calculated in a manner similar to the common financial metric Internal Rate of Return (IRR). First, an estimate of the social cash flows is made for the life of the project. Social cash flows are cash flows generated by a project over and above the cash flows that would normally be generated. Environmental cash flows are part of social cash flows. For eximple, if a business venture generated greenhouse gas emissions permits that can be sold on an emissions trading market similar to the Emission Trading Scheme in the European Union, the resultant cash inflows are estimated. The discount rate at which the present value of these cash inflows equals the capital investment is the SRO1. The SROI is equivalent to an IRR calculated using social cash flows.

SROI supports sustainability by providing investors and managers with a metric that allows for analysis of the social return for a given amount of investment. Investors who are interested in supporting sustainability can use SROI 10 differentiate between firms based on their social return.

\section{Emissions trading programs}

Emissions trading programs are cap-and-trade programs that respond to the climate change problem through the trading of emissions allowances. The cap-and-trade approach to controlling emissions originated in the sulphur dioxide $\left(\mathrm{SO}_{2}\right)$ markel. $\mathrm{SO}_{2}$ is a precursor to acid rain. A central authority, usually a government agency, sets an aggregate limit or cap on the amount of a pollutant that a set of entities (e.g. the utilities industry) can emil over a defined period. There have also been calses where an individual firm sets an aggregate limit for the total emissions of its companies or divisions (e.g., BP, formerly British Petroleum). Emission allowances are allocated to the individual firms based on historical emissions by the individual firms. The allowances represent the right to emit a specified amount of pollutant. The total amount of credits equals the aggregate cap, thus limiting total enissions. Firms that pollute beyond their allowances must buy credits from those who pollute less than their allowances. This transfer is called a trade, which may be made on a climate exchange, directly with other participants, or through a broker.

The overall goal of emissions trading is to reduce air pollution. The effect of emissions trading is that the buyer must pay to pollute, while the seller is rewarded for reducing emissions. Consistent with the law of supply and demand, the more entities there are that need to buy credits, the higher the price of the credits becomes. Reducing emissions becomes cost-effective in comparison. In some systems. the aggregate cap is lowered over time. In others, a portion of all traded credits must be retired, resulting in a net reduction in emissions each time a trade occurs. In many cap-and-trade systems, organizations that do not pollute may also buy credits. This allows envirommental groups to purchase and retire pollution credits to reduce emissions and raise the price of the remaining credits. While the cap is usually set by a political process, individual firms freely choose how or if they will reduce their emissions. Moreover, the government does not need to regulate how much each individual firm emits, making cap-and-1rade a very cost-effective method for controlling pollution on a large scale. 
Emissions trading supports sustainability by controlling air pollution. It uses free markets to provide economic incentives for reducing emissions of pollutants and economic penalties for exceeding pre-specified emission limits.

\section{Internal reporting tools and techniques}

In this section we will discuss the prominent internal reporting tools that firms use to support sustainability. In Table 10.2 we summarize these tools by presenting disciplinary roots, key contributors, a shor description, stakeholders, and the outcomes resulting from using these tools.

\section{Sustainable balanced scorecard}

The sustainable balanced scorecard links sustainability management to business strategy to achieve recognition of sustainability issues in a company's strategic plan. The balanced scorecard is an internal assessment, improvement, and reporting system. It supplies key indicators for management to perform its function. The key to the scorecard's success is the link to the firm's strategic plan. The successful implementation of this management system turns strategy into action.

The conventional scorecard measures performance by combining financial measures with non-financial measures, from the following perspectives: (1) financial; (2) customer; (3) internal business processes; and (4) learning-and-growth. The balancing is done by including nonfinancial measures (customer, internal business processes, and learning-and-growth) with conventional financial accounting measures. Learning-and-growth opportunities facilitate improvements to business processes, and also provide incentives for employees to increase their intellectual capital. For example, a learning-and-growth metric is the number of hours of continuing education training by management. Other examples are provided by Kaplan and De Pinho (2007: 19-20) in their exhibits. They refer to the learning-andgrowth perspective as the human resource perspective.

The original balanced scorecard has been expanded to manage sustainability (Epstein and Wisner 2001: Figge et al. 2002: Idalina and Reijnders 2005; ldalina er al. 2002). There are two methods of incorporating sustainability into the balanced scorecard. Sustainability can be incorporated as part of any or all of the four standard perspectives. For example, in the internal process perspective, the objectives "Energy, Water and Material Efficiency" and "Elimination of Animal Testing on Products" would incorporate sustainability. In the customer perspective the objectives "Toxin-Free Product" and "Products Free of Animal Testing" would incorporate sustainability. An altemative method is the creation of an additional perspective that focuses on sustainability. The advantage of the first method is that sustainability is better integrated into the measurement system and becomes embedded in the corporate culure. If a company has a separate scorecard specifically for sustainability without also integrating sustainability into the main balanced scorecard, then sustainability does not get the appropriate emphasis by top decision makers in the firm. 
Table 10.2 Summary of internal reporting tools and techniques

\begin{tabular}{|c|c|c|c|c|}
\hline & $\begin{array}{l}\text { Sustainable balanced } \\
\text { scorecard }\end{array}$ & Eco-efficiency & $\begin{array}{l}\text { Environmental costs and } \\
\text { product pricing }\end{array}$ & Environmental sustainability indexes \\
\hline $\begin{array}{l}\text { Disciplinary } \\
\text { roots }\end{array}$ & $\begin{array}{l}\text { Strategic management } \\
\text { and accounting }\end{array}$ & $\begin{array}{l}\text { Finance, accounting, } \\
\text { environmental science, } \\
\text { and engineering }\end{array}$ & $\begin{array}{l}\text { Management, accounting, } \\
\text { manufacturing, and } \\
\text { engineering }\end{array}$ & $\begin{array}{l}\text { Sociology, economics, } \\
\text { environmental science }\end{array}$ \\
\hline $\begin{array}{l}\text { Key } \\
\text { contributors }\end{array}$ & $\begin{array}{l}\text { Kaplan and Norton } \\
(1992,1993,1996 a, \\
1996 b, 1996 \mathrm{c}) \text {; Epstein } \\
\text { and Wisner (2001); Figge } \\
\text { et al. (2002); Idalina and } \\
\text { Reinders (2005); Idalina } \\
\text { et al. (2002) }\end{array}$ & Schaitegger and Sturm (1989) & Kaplan and Bruns (1987) & $\begin{array}{l}\text { Center for Environmental Law } \\
\text { and Policy at Yale; Center for } \\
\text { International Earth Science } \\
\text { Information Network at Columbia; } \\
\text { World Economic Forum }\end{array}$ \\
\hline $\begin{array}{l}\text { Description } \\
\text { of tool or } \\
\text { technique }\end{array}$ & $\begin{array}{l}\text { An internal assessment. } \\
\text { improvement. and } \\
\text { reporting system that } \\
\text { includes sustainability } \\
\text { in the strategic plan }\end{array}$ & $\begin{array}{l}\text { Ratio betwecn two elements: } \\
\text { environmental impact (to } \\
\text { be reduced) and value of } \\
\text { production (10 be increased) }\end{array}$ & $\begin{array}{l}\text { Activity-based system that } \\
\text { is the basis for allocaling } \\
\text { environmental costs to } \\
\text { products and processes }\end{array}$ & $\begin{array}{l}\text { Indices that provide a methodology } \\
\text { to understand how firms actions } \\
\text { impact aggregate sustainability } \\
\text { in a specific country }\end{array}$ \\
\hline Stakeholders & $\begin{array}{l}\text { Management, employees. } \\
\text { customers, stockholders. } \\
\text { and creditors }\end{array}$ & $\begin{array}{l}\text { Management, stockholders, } \\
\text { and society }\end{array}$ & $\begin{array}{l}\text { Management and } \\
\text { consumers }\end{array}$ & $\begin{array}{l}\text { Management, economists, researchers, } \\
\text { government agencies, environmental } \\
\text { protection agencies, society }\end{array}$ \\
\hline Outcomes & $\begin{array}{l}\text { Integrates sustainable } \\
\text { management into } \\
\text { mainstream business } \\
\text { management }\end{array}$ & $\begin{array}{l}\text { Reduces the damage caused } \\
\text { to the environment while } \\
\text { increasing. Or at least not } \\
\text { decreasing, shareholder value }\end{array}$ & $\begin{array}{l}\text { Promotes management } \\
\text { awareness of environmental } \\
\text { and social impact of } \\
\text { products/processes in order } \\
\text { to realize cost savings and } \\
\text { select products/processes } \\
\text { that are more sustainable }\end{array}$ & $\begin{array}{l}\text { Provides management with } \\
\text { environmental indicators and } \\
\text { statistics for internal decision } \\
\text { making about doing business in a } \\
\text { particular country }\end{array}$ \\
\hline
\end{tabular}


A balanced scorecard management system that incorporates sustainability gives management a tool to implement a strategic plan that includes sustainability goals. It offers a promising starting point for incorporating environmental and social aspects into the main management system. Sustainability management using a balanced scorecard helps to overcome the shortcomings of conventional approaches to environmental and social management systems by integrating the three pillars of sustainability (social, environmental, and economic perspectives) into a single and overarching strategic management tool (Figge et al. 2002). A balanced scorecard management system supports sustainability by integrating sustainability management into mainstream business management.

\section{Eco-efficiency}

Eco-efficiency describes a set of methods that provide information on environmental performance vis-à-vis financial performance. The concept was first defined by Schaltegger and Sturm in 1989 as a ratio between two elements: environmental impact (to be reduced) and value of production (to be increased). Eco-efficiency is based on the concept of creating more goods and services by using fewer resources and creating less waste and pollution. Eco-efficiency became widely accepted when the World Business Council for Sustainable Development (WBCSD) promoted it in its publication Changing Course (Schmidheiny 1992). The WBCSD (1996) includes a clear target level: An eco-efficient state is reached when economic activities are at a level at least in line with the earth's estimated carrying capacity. The United Nations Conference on Environment and Development in 1992, commonly known as the Earth Summit, also endorsed ecoefficiency in the adoption of Agenda 21, a universal blueprint for sustainable development in business.

The term eco-efficiency has since become associated with a management philosophy supportive of sustainability. DeSimone and Popoff (1997: 24-39) offer a comprehensive discussion of the financial benefits of eco-efficiency. These include: (1) reduced current costs of poor environmental performance; (2) reduced future costs of poor environmental performance: (3) reduced costs of capital; (4) benefits from increased market share and improved or protected market opportunities: and (5) benefits from enhanced image.

Eco-eficiency indicators are based on the Manual for the Preparers and Users of Eco-afficiency Indicators, developed by the United Nations Conference on Trade and Development (UNCTAD 2004). Eco-efficiency guideline areas are: (1) water use; (2) energy use; (3) global warming contribution, (4) ozone depleting substances: and (5) waste. The guideline also includes case examples. Eco-efficiency indicators provide information in a systematic and consistent manner over periods of time to enhance comparability. The manual therefore covers the technical issues of recognition, measurement, and disclosure of envirommental transactions and variables.

Schattegger (1998: 284-285) describes a structured management decisionmaking process. the Eco-rational Patl Method (EPM), to guide a fim to 
eco-efficiency by integrating traditional accounting information (e.g., revenues, costs, expenses, income) - the "economic dimension" - with environmental accounting information (e.g., emissions, resource use) - the "ecological dimension." First, the firm gathers traditional financial results, including environmental compliance costs and earnings. Second, the firm uses environmental accounting to evaluate the ecological harm caused by the firm in units of environmental impact. Third, the firm uses regular accounting measures of economic efficiency (e.g., contribution margin per product). Fourth, the firm computes ecological efficiency (e.g., environmental impact added per product). Finally, eco-efficiency is calculated (e.g., the monetary contribution margin created per environmental inpact added for a product). Ciba Specialty Chemicals Inc. (2006), a Swiss public company, provides an easily accessible example of eco-efficiency metrics in all five guideline areas for the 2002-2006 period.

Eco-efficient strategies, measured by eco-eficiency indicators, support sustainability by providing sustainability metrics that allow management to reduce the damage caused to the environment while increasing, or at least not decreasing, shareholder value (Schaltegger and Sturm 1989).

\section{Impact of environmental costs on product pricing}

The impact of environmental costs on product pricing considers whether environmental costs are appropriately included in the product price. Because of the costs related to compliance with environmental laws and regulations, firms include environmental costs related to past danage, as well as preventative costs, in product pricing. Past unrecognized costs - for example, costs related to the products whose production resulted in the creation of an environmental hazard - would have resulted in under-costing of these products at the time of production.

Current environmental costs should be assigned to the correct product(s). If these costs are instead included in a general overhead rate, products that cause the environmental costs will have costs understated and profit overstated. Accurate cost allocation will help a firm make appropriate product retention/elimination decisions. Activity-based costing (Kaplan and Bruns 1987) is one way of assigning costs appropriately.

Stakeholders expect firms to be responsible for the environmental and social costs of their products throughout the product's life cycle (see also Chapters 5. 8,11 , and 12 in this volume). For example, two recent European Union directives. the Restriction of Hazardous Substances Directive, effective in 2006, and the Walste Electrical and Electronic Equipment Directive, effective in 2003, require firms to eliminate certain hazardous materials in the design/production phase and to be responsible for the end-of-iffe disposal/recycling costs of their products.

Firms report on their efforts to better understand environmental costs. For example, Ford's 2005-2006 Sustainability Report provides a good example of the analysis of environmental and social costs incurred along its value chain. In addition, Toyota's approach to understanding the environmental and social costs of producing a product demonstrate the impact this topic can have on making 
sustainable decisions. The basis of Toyota's model, with its emphasis on Philosophy, Processes, People and Partners, and Problem Solving, is to "base management decisions on a long-term philosophy, even at the expense of short-term financial goals" (Liker 2004: 13).

Recognizing that product costs include environmental costs can help management decide what products to offer. As managers become aware of the environmental impact of their products and processes, they will select products that are more sustainable.

\section{Environmental sustainability indexes}

Environmental sustainability indexes track the environmental and social performance of countries. The Environmental Performance Project includes two country-level indices, namely the Environmental Sustainability Index and the Environmental Performance Index. The purpose of the project is to shift environmental decision making to firmer analytic foundations by using environmental indicators and statistics. This is a joint project between the Yale Center for Environmental Law and Policy at Yale University, the Center for International Earth Science Information Network at Columbia University, and the World Economic Forum. The project produces a periodically updated Environmental Sustainability Index, which is a composite index tracking a diverse set of socioeconomic, environmental, and institutional indicators that characterize and influence envirommental sustainability and are aggregated at the country level. The second index is the Environmental Performance Index, which focuses on assessing key environmental policy outcomes using trend analysis and performance targets (Yale University 2006).

The Environmental Sustainability Index benchmarks the ability of nations to protect the environment. It does so by integrating 76 data sets into 21 indicators of environmental sustainability. tracking natural resource endowments. past and present pollution levels, environmental management efforts, and the capacity of a society to improve its environmental performance. The 2005 Environmental Sustainability Index provides indicators that permil comparison across a range of issues that fall into five broad categories: Environmental Systems: Reducing Environmentit Stresses; Reducing Human Vulnerability 10 Environmental Stresses: Societal and Institutional Capacity to Respond to Environmental Challenges; and Global Stewardship (Yale University 2006).

The Environmental Performance Index provides a tool for improving policymaking and shifing environmental decision making onto firmer analytic foundations. ll provides benchmarks for current national pollution control and natural resource management resulis. It also identifies specific targets for environmental performance and measures how close each country cones to these established goals. Issue-by-issue and aggregate rankings facilitate cross-country comparisons both globally and within relevant peer groups. The 2006 Environmental Performance Index centres on two broad environmental protection objectives: (1) reducing environmental stresses on human health; and (2) protecring ecosystem vitality. 
It is derived from a review of the environmental literature and mirrors the priorities expressed by policy makers, most notably the environmental dimension of the United Nations' Millennium Development Goals. In the 2006 Environmental Performance Index, environmental health and ecosystem vitality are gauged using 16 indicators tracked in six established policy categories: Environmental Health; Air Quality; Water Resources; Biodiversity and Habitat; Productive Natural Resources; and Sustainable Energy. It also provides "Environmental Performance Indicator Rankings by Country," based on the six policy categories (Yale University 2006).

The indices support sustainability by providing management with environmental indicators and statistics for internal decision making regarding doing business in a particular country. This is particularly important with the extent of globalization in business, because the components of the indices can help managers understand a country's business and regulatory environment.

\section{External reporting tools and techniques}

In this section we will discuss the external reporting tools and techniques that firms use to support sustainability. In Table 10.3 we summarize these tools by presenting disciplinary roots, key contributors, a short description, stakeholders, and the outcomes resulting from using the tool.

\section{Environmental liabilities}

Environmental liabilities are reported by firms in their annual reports to disclose the current cost of environmental obligations related to past or current operations. Liabilities are defined as economic obligations that arise from benefits received in the past, and for which the probability, amount, and timing of payment are known with reasonable certainty. Generally accepted accounting principles require that environmental liabilities be disclosed in the balance sheet, along with the firm's other liabilities. The Environmental Protection Agency (EPA) definition of an environmental liability is a legal obligation to make a future expenditure due to the past or ongoing manufacture, use, release, or threatened release of a particular substance, or other activities that adversely affect the environment.

The term liability has accounting and legal dimensions (Rogers 2005: 19-30). The accounting dimension is that a liability is a present obligation to make a future expenditure. Significant challenges arise with regard to environmental liabilities. Even if there is acknowledgement that an obligation has been incurred, there may be ambiguity about whether the obligation is measurable. When there is ambiguity with regard to liabilities, management has inherent bias and incentive to understate liabilities to show a healthier financial position because excessive liabilities have a detrimental effect on the financial well-being of a firm. This leads to the legal dimension, where a liability is a legally enforceable obligation. If management does decide to record an environmental liability in the financial statements or even as a note to the financial statements, this may be 


\begin{tabular}{|c|c|c|c|c|}
\hline & Environmental liabilities & $\begin{array}{l}\text { Financial reporting of } \\
\text { emission credits }\end{array}$ & $\begin{array}{l}\text { Sustainability reporting based } \\
\text { on Global Reporting Initiative } \\
\text { Guidelines }\end{array}$ & $\begin{array}{l}\text { Greenhouse Gas Accounting } \\
\text { and Reporting Standard and } \\
\text { Guidance }\end{array}$ \\
\hline $\begin{array}{l}\text { Disciplinary } \\
\text { roots }\end{array}$ & Accounting. law & Accounting & $\begin{array}{l}\text { Accounting, operations } \\
\text { management }\end{array}$ & $\begin{array}{l}\text { Accounting, environmental } \\
\text { science }\end{array}$ \\
\hline $\begin{array}{l}\text { Key } \\
\text { contributors }\end{array}$ & $\begin{array}{l}\text { International Accounting } \\
\text { Standards Board: Rogers } \\
(2005)\end{array}$ & $\begin{array}{l}\text { International Financial } \\
\text { Reporting Interpretations } \\
\text { Committee; Rogers (2005) }\end{array}$ & Global Reporting Initiative & $\begin{array}{l}\text { World Resources Institute, } \\
\text { World Council on Sustainable } \\
\text { Developnent }\end{array}$ \\
\hline $\begin{array}{l}\text { Description } \\
\text { of tool or } \\
\text { technique }\end{array}$ & $\begin{array}{l}\text { Recognizing, measuring, } \\
\text { and reporting } \\
\text { environmental liabilities } \\
\text { in financial slatements }\end{array}$ & $\begin{array}{l}\text { Recognizing, measuring, and } \\
\text { reporting of emission credit } \\
\text { assets and liabilities }\end{array}$ & $\begin{array}{l}\text { Recognizing, measuring, and } \\
\text { reporting of environmental and } \\
\text { social strategies and metrics }\end{array}$ & $\begin{array}{l}\text { Recognizing, measuring, setting } \\
\text { reduction targets, and reporting } \\
\text { of greenhouse gas emissions }\end{array}$ \\
\hline Stakeholders & $\begin{array}{l}\text { Shareholders. } \\
\text { environmental groups, } \\
\text { environmental protection } \\
\text { agencies. altomeys }\end{array}$ & $\begin{array}{l}\text { Shareholders, environmental } \\
\text { groups, government agencies, } \\
\text { emissions trading programs }\end{array}$ & $\begin{array}{l}\text { Shareholders, environmental } \\
\text { groups, employees, management, } \\
\text { and insurers }\end{array}$ & $\begin{array}{l}\text { Shareholders, environmental } \\
\text { groups. management, } \\
\text { government agencies }\end{array}$ \\
\hline Outeornes & $\begin{array}{l}\text { Discloses firms' } \\
\text { financial responsibility } \\
\text { for environnental } \\
\text { remediation. The } \\
\text { requirement to report } \\
\text { liabilities discourages } \\
\text { management from } \\
\text { engaging in damaging } \\
\text { econonic activities }\end{array}$ & $\begin{array}{l}\text { Firms' emission credits may } \\
\text { be reported as an intangible } \\
\text { asse or liability }\end{array}$ & $\begin{array}{l}\text { The exercise of achieving } \\
\text { GRl compliance can focus the } \\
\text { efforts of the firm on measurable } \\
\text { environmental and social actions }\end{array}$ & $\begin{array}{l}\text { Reduction of greenhouse gases } \\
\text { by firms to affect climate change }\end{array}$ \\
\hline
\end{tabular}


used as evidence of acknowledgement of guilt in legal proceedings and may, from management's perspective, put the company at greater risk of losing in court. Research shows that there is significant variation in the quality of financial statement disclosures on estimated environmental cleanup liabilities. The factors influencing these disclosures include regulatory enforcement, litigation and negotiation concerns, and capital market concerns (Barth et al. 1997).

The valuation of environmental liabilities can be problematic. The three issues are timing, amount, and likelihood. Payments of compliance and remediation obligations, for example, may be many years away and may stretch out over a long period of time. Compensation and natural resource damage liabilities, on the other hand, can arise in the near term but also have long timeframes. Different environmental liabilities may occur with different likelihoods. One way to consider the expected cost of environmental liabilities is to multiply the forecasted magnitude of the expense by its likelihood. This likelihood should account for factual and legal questions, and thus requires scientific and legal analysis. A more complete way to account for an uncertain liability is to calculate its expected cost based on a probability distribution of expense magnitudes. Estimates of future costs also have unavoidable uncertainties about magnitude of costs. The recommendation is to apply the standard uncertainty assessment methods of sensitivity and scenario analysis.

The disclosure of environmental liabilities makes company environmental performance more transparent. This transparency discourages management from engaging in economic activities that damage the environment. For existing environmental damage, mandatory disclosure forces firms to recognize the need to mitigate the damage.

\section{Financial reporting of emission credits}

Financial reporting of emission credits is related to emissions trading programs. This type of financial reporting recognizes whether a firm is holding excess emission credits or whether it has an obligation to purchase credits. The International Financial Reporting Interpretations Committee (IFRIC) issued an interpretation. IFRIC 3, on emission rights. Emission credits are recognized as intangible assets, but the interpretation also requires the recognition of the corresponding liability. Under IFRIC 3, emission credits are initially valued at fair value (i.e., as bought or sold in a current transaction between willing parties). The asset and liability are shown separately and are not offset against one another (Rogers 2005: 198-199). Although this accounting treatment remains conceptually sound and represents the economic reality of cap-and-trade transactions, IFRIC 3 has now been willdrawn after intense pressure from European politicians and business leaders who objected to the financial consequences of these disclosures.

\section{Sustainability reporting based on Global Reporting Initiative Guidelines}

Sustainability reporting based on Global Reporting Initiative Guidelines promotes the development and dissemination of globally applicable sustainability 
reporting that discloses economic, environmental, and social dimensions of the organization's activities, products, and services. Founded in 1997 by the Coalition for Environmentally Responsible Economies and the United Nations Environmental Program, the GRI employs a long-term, multi-stakeholder process to develop and disseminate globally applicable sustainability reporting guidelines (Global Reporting Initiative 2006; White 2003). These guidelines are currently in voluntary use by over 1,000 organizations for reporting on the economic, environmental, and social dimensions of their activities, products, and services.

A number of countries in Europe require some sustainability reporting (Waddock 2004). EU countries have shown a particularly strong interest in Sustainable Development Reporting. For instance in France, Germany, Denmark, Sweden, the United Kingdom, and Norway, it is already mandatory for corporations to disclose some form of environmental and/or social metrics. Other countries such as the Netherlands, and South Africa also have disclosure requirements. In the United States, sustainability disclosure is not yet required.

The GRI continues to work with the International Federation of Accountants' International Auditing and Assurance Standards Board to enhance the credibility of the GRI criteria. In their report on the future of sustainability assurance, Zadek and Raynard (2004) suggest the need to develop Generally Accepted Accounting Principles and Assurance Standards for Sustainability.

Some firms integrate sustainability reporting into their annual report. The sustainability disclosure is integrated in the report as opposed to reporting in separate sections of the report or in a separate report. For example, Novo Nordisk's annual report includes their sustainability reporting.

GRI supports sustainability by providing an established framework for an organization to report on its environmental and social performance. The framework facilitates the evaluation of a company's environmental and social performance. A firm's performance can be assessed over a number of years or compared to other firms in the same industry.

\section{Greenhouse Gas Accounting and Reporting Standard and Guidance}

Greenhouse Gals Accounting and Reporting Standard and Guidance assists firms in understanding and reporting their impact on global warming. Generally, greenhouse gals measurement and reporting is a section of a firm's sustainability report that is prepared based on Global Reporting Initiative (GRI) guidelines. Some tims prepare an annual report that includes their sustainability report (e.g.. Novo Nordisk 2005 annual report). Because the greenhouse gas area of reporting is significant for many firms, the GRI guidelines refer to the Greenhouse Gas Corporale Accounting and Reporting Standard protocol for guidance. The Greenhouse Gas Corporate Accounting and Reporting Standard is a document that was prepared and is continuously improved through a joint venture of the World Resources Institute and the World Counci! on Sustainable Development. The mission of the Greenhouse Gas Corporate Accounting and Reporting Standard is to develop internationally accepted greenhouse gas (GHG) accounting and reporting standards for business and 10 promote broad adoption of the standard. The 
standard provides a step-by-step guide for companies to use in quantilying and reporting their GHG emissions.

The Greenhouse Gas Accounting and Reporting Standard has three key steps: (1) prepare an inventory of greenhouse gases emitted as a result of the firm's existence; (2) set a greenhouse gas target; and (3) develop a plan to reduce greenhouse gases over time. A common approach is to set a larget to reduce greenhouse gases by a future date to a level that existed for the entity at a previous time. For example, BP set a goal to reduce annual emissions to 90 percent of 1990 levels by $2010 .^{1}$

Possible future programs related to greenhouse gases include emissions trading programs such as the European Union Greenhouse Gas Emissions Allowance Trading Scheme that became effective at the beginning of 2005. This topic was discussed in the section above entitled "Emissions Trading Programs."

The Greenhouse Gas Accounting and Reporting Standard is designed to be program- and policy-neutral so a variety of GHG programs can use the Standard as their accounting and reporting protocol. The Standard does not include a verification process. However, if the GHG Standard is used as part of the GRI reporting guidelines it will include the GRI verification process. Cross-sector and sector-specific calculation tools are part of the GHG Standard. In a manner similar to financial statements prepared based on generally accepted accounting principles, the Greenhouse Gas Accounting and Reporting Standard is guided by principles rather than rules. The principles of the standard are relevance, completeness, consistency, transparency, and accuracy.

Because of growing international concem about causes of climate change that include greenhouse gases emitted by firms, the measurement, reporting, and planned reduction of these gases by firms helps support sustainability.

\section{Conclusion}

Financial managers in today's business environment must employ tools and techniques that support sustainability. In this chapter we presented these tools and techniques in three categories, namely finance, internal reporting, and external reporting. In the finance category we discussed topics with disciplinary roots in finance, debt and equity investing, and stock exchanges. Key contributors include the Social Investment Forum, the United States Environmental Protection Agency. the European Union and Lingane and Olsen (2004). These tools and techniques impact the following stakeholders; shareholders; employees; fund managers; investors; management; venture capitalists; government entities; and future generations. The outcomes from the use of these tools provide an investment outlet for investors who support sustainability, provide an additional source of capital for firms with a sustainable mission, and allow investors and management to evaluate the social return on their investment. Emissions trading programs reduce the total amount of pollutants in the air.

In the internal reporting category we discussed topics with disciplinary roots in strategic management, accounting, finance, manufacturing, environmental 
science, engineering, sociology, and economics. Key contributors include Kaplan and Norton (1992, 1993, 1996a, 1996b, 1996c), Schaltegger and Sturm (1989), Kaplan and Bruns (1987), Center for Environmental Law and Policy at Yale University, Center for International Earth Science Information Network at Columbia University, and the World Economic Forum. These tools and techniques impact the following stakeholders: management; employees; customers; stockholders; and creditors. The outcomes from the use of these tools include the integration of sustainable management into mainstream business management and reduction of the damage caused to the environment, while not decreasing shareholder value. Managers and employees also become aware of the environmental and social impact of their products and processes. Furthermore, management is provided with environmental indicators and statistics regarding doing business in a particular country.

In the external reporting category we presented topics with disciplinary roots in accounting, law, operations management, and environmental science. Key contributors include the International Accounting Standards Board, the International Financial Reporting Interpretations Committee, the Global Reporting Initiative, the World Resources Institute and the World Council on Sustainable Development. These tools and techniques impact shareholders, environmental groups, environmental protection agencies, government agencies, emissions trading programs, employees, management, insurers, and attorneys. The outcomes from the use of these tools include disclosure of financial responsibility for environmental remediation, reporting of emission credits as an intangible asset or liability, and the reduction of climate-changing greenhouse gases by firms.

By adopting these tools and techniques, the degree to which a firm supports sustainability increases. The first step for determining the appropriate sustainability tools for a firm is to become aware of the tools that are available; this is one of the objectives of this chapter. As firms continuously improve and observe trends in their industry, they will receive guidance on developing their understanding of the tools that are appropriate. Firms can receive assistance in tool selection through their involvement in industry associations. Internal and external auditors will provide expertise regarding the use of these tools and techniques. The selection and implementation of tools will be specific to the firm, industry, and country. For example, energy companies will need to select an emissions trading tool to trade their emission permits, while an insurance company will have less need for a tool of this kind.

The challenges in adopting these tools are partly a consequence of the expertise needed for successful implementation. Nongovernmental organizations (NGOs) can provide this expertise to firms. For example. the California Climate Action Registry provides a web-based tool for firms to calculate and report their greenhouse gas emissions. NGOs also provide documents (many of which are referenced in this chapter) that are helpful in training firms to use these tools. Another significant challenge is the interdisciplinary nature of many of these tools. For example, understanding of eco-efficiency indicators requires scientific. environmental, and financial expertise. 
Climate tools will become more prominent in the foreseeable luture. In particular, there are many exchanges for trading of $\mathrm{CO}_{2}$ emissions, the most prominent being the Emissions Trading Scheme in the European Union. As more firms are required by regulation to account for and trade their emissions, the maikets to trade these permits will become more prominent. Because of the current global focus on climate change, one key area of future research is climate-related tools and techniques.

\section{Questions for reflection}

Here are three questions for your further reffection on the issues broached in this chapter:

- Which financial management tools to support sustainability apply to your industry or firm?

- What voluntary or mandatory sustainability reporting exists in your industry?

- What opportunities or requirements exist for your firm's participation in an emissions trading scheme?

\section{Note}

1 http://www.gsb.stanford.edu/PMP/pdts/ClinateChange_2005PMl.pdf

\section{References}

Barth, M.E., McNichols, M.F., and Wilson, G.P. (1997) "Factors infuencing firms" disclosures about environmental liabilities," Review of Accolming Studies, 2, 1, 3565.

Ciba Specialty Chemicals Inc. (2006) Eco-efficiency Indicators. Online. Available HTTP: <http://ww.cibasc.com/index/enp-index/crilp-ehs/emp-ehs-efficiency.htm> (accessed 3 July 2007).

DeSimone, L.D. and Popoff, F. (1997) Eco-Efficiency: The husiness link ro sustainahility Cambridge and London: MIT Press.

Epstein, M.J. and Wisner. P.S. (2001) "Using a balanced scorecard to impiement sustainability," Environmental Quality Managenent, 11, 2, 1-10.

Figge, F., Hahn, T., Schaltegger, S., and Wagner, M. (2002) "The sustainability balanced scorecard: Linking sustainability management to business strategy." Business Strutegy and the Environmen, 11, 5, 269-284.

Global Reporting Initiative (2006) Sustainability Reporting Guidelines, Version 3. Online. Available HTTP: <http:/ww'w.globalreporting.org/NR/rdonlyres/A1FB550l-BODE4B69-A900-27DD8A4C2839/0/G3_GuidelinesENG.pdf> (accessed 3 May 2007).

Idalina, D. and Reijnders, L. (2005) "Evaluating environnental and social perfomance of large Portuguese companies: A balanced scorecard approach," Businexs Strategy and the Environment, 14, 2, 73-9I.

Idalina, D., Reijnders, L., and Antunes, P. (2002) "From envirommental performance evaluation to eco-efficiency and sustainability balanced scorecards." Environmenol Quainy Management, 12, 2, 51-64. 
Kaplann, R.S. and Bruns, W. (1987) Accounting and Management: Field study perspecives, Boston, MA: Harvard Business School Press.

Kaplan, R.S. and De Pinho, R.R. (2007) Amanco: Developing the sustainability scorecard. Online. Available HTTP: <http://doi.contentdirections.conv/mr/hbsp.jsp?doi=10.1225/ 107038> Harvard Business School Case, \# 9-107-038.

Kaplan, R.S. and Norton, D.P. (1992) "The balanced scorecard: Measures that drive performance," Harvard Business Review, 70, 1, 71-79.

Kaplan, R.S. and Norton, D.P. (1993) "Putting the balanced scorecard to work," Har'ard Business Review, 71, 5, 134-142.

Kaplan, R.S. and Norton, D.P. (1996a) The Balanced Scorecard, Boston, MA: Harvard Business School Press.

Kaplan, R.S. and Norton, D.P. (1996b) "Linking the balanced scorecard to strategy," California Management Review, 39, 1, 53-77.

Kaplan, R.S. and Norton, D.P. (1996c) "Using the balanced scorecard as a strategic management system," Harvard Business Review, 74, 1, 75-85.

Liker, J. (2004) The Toyota Way, New York: McGraw Hill.

Lingane, A. and Olsen, S. (2004) "Guidelines for social return on investment," California Management Review, 46, 3, 116-135.

Rogers, C.G. (2005) Financial Reporting of Environmental Liabilities and Risks after Sarbones-Oxley, Hoboken, NJ: Wiley.

Schaltegger, S. (1998) "Accounting for eco-efficiency," in B. Nath, L. Hens, P. Compton, and D. Devuyst (eds), Environmental Management in Practice. Volume I: Instruments for Enironmental Management, London: Routledge, pp. 272-287. Reprinted in B. Bartelmus and E.K. Seifert (eds) (2003) Green Accouming, Aldershot: Ashgate Publishing.

Schaltegger, S. and Sturm, A. (1989) Ökologieinduzierte Entscheidungsprobleme des Managements: Ansatzpunkte zur Ausgestaltung ion Instrumenten |Ecology-induced management decision support: Starting points for instrument formation], Basel: WWZ.

Schmidheiny, S. (1992) Changing Course: A global business perspective on development and the environment, Cambridge, MA and London: The MIT Press.

Social Investment Forum (2006) 2005 Report on Socially Responsible Imesting Trends in the United States: 10-year review: Online. Available HTTP: <http:/www socialinvest. org/areas/research/trends/sri_trends_report_2005.pdf $>$ (accessed 3 May 2007).

UNCTAD (United Nations Conference on Trade and Development) (2004) A Mamual for the Preparers and Users of Eco-Efficichly Indicators. New York and Geneva: United Nations.

Waddock. S. (2004) Corporate Disclesure of Social and Envirommental Dara: Mandatory is rolumar: Online. Avallable HTTP: <htp://www.becc.net/index ofm?tuseaction= Page, viewPage \& pageld=1 172 \& nodel $=3 \&$ parentID=1 170 \& grandparent ID=885> (accessed 3 May 2007).

WBCSD (World Business Council on Sustainable Development) (1996) Eco-Efficient Latership for Improred Economic and Enirommental Performance, Geneva: WBCSD.

White, A.L. (2003) "Improving sustainability disclosure: The global reporting initiative guidelines," in S. Wainge (ed.). Ants, Golileo, \& Gandhi: Designing the fintire of business through nature genius and compassiom. Shetfield: Greenleat Publishing.

Yale University (2006) Emirommenal Measurement Project. Online. Available HTTP: <htip://www.yalc.edu/esi/> (accessed 3 May 2007).

Zadek, C. and Raynard. P. (20)4) RR86 - The Future of Sustainability Assurance. Online. Available HTTP: <hap://www/accaglobal.com/publicinterest/activities/research/reports/ sustainable_and_lransparent/rr-086> (accessed 3 May 2007). 